\title{
Justifiable Killing in War? For Taking the Soldier's Stance Seriously in War Ethics
}

\author{
Angela Kallhoff
}

The paper builds on a current debate in the philosophy of war, which are rules that contribute to the containment of war and to a system of fair rules in warfare. Both are key issues in the "jus in bello" as a central part of war ethics. Recently, philosophers have questioned a general exculpation of soldiers in that context. Instead of restricting the debate on "justifiable killing" to the "jus ad bellum," which explores moral restrictions in starting warfare, philosophers examine moral implications when soldiers kill in war. Even though epistemic limitations and duties of soldiers need to be taken into account, the paper argues for a more detailed exploration of acts of killing in war by soldiers.

Just war theory, jus in bello, war ethics, liability, morality of warfare

Angela Kallhoff is Univ.-Prof. of Ethics with special emphasis on Applied Ethics at the Department of Philosophy, University of Vienna. She is also head of the research platform Nano-Norms-Nature. Her research interests comprise Aristotelian ethics, ethics of nature, political philosophy and war ethics. Recent book publications: Climate Justice and Climate Ethics (ed. Berlin/Boston 2015); Political Philosophy oft he Citizen (Wien/ Köln/Weimar 2013); Why Democracy Needs Public Goods (Lanham 2012); Ethical Naturalism after Aristotle (Paderborn 2010).

\section{Introduction}

Since ancient times, philosophers and political scientists have been interested in the ethics of warfare (Bellamy 2006). An outcome of debates of this long history is a set of principles and arguments that together form a theoretical approach which is "just war theory." Even though this theory is not a systematically argued approach, it is accepted as a collection of normative principles regarding warfare (Frowe 2011). Much of the content of this collection of normative guidelines has also become part of the legally binding Law of the Peoples.

This body of theories is also the background for current debates in moral philosophy. Philosophers of our days are interested in developing a war ethics that fulfills two purposes. They argue that moral philosophy should expand on and comment the current Law of the Peoples. Some of the most important contributions to this debate, including Walzer's famous book, Just and Unjust War. A Moral Argument with Historical Illustrations (Walzer 2006), has been developed against the backdrop of that "legalist paradigm," which "consistently reflects the 
conventions of law and order. It does not necessarily reflect the arguments of lawyers, though legal as well as moral debate has its starting point here" (Ibid., 61). In particular, just war theory has focused on a paradigmatic case of warfare that is framed as a military battle among nation states. Even though it is in itself a "crime" (ibid., 21-33), war is regarded as an issue that needs moral assessment, while acts of killing in war especially need to be justified. Moreover, contemporary authors in war ethics also try to highlight new moral issues that comprise some of the most pressing questions of our day; namely, how does terrorism need to be addressed in an ethical framework (Coady 2004; Goodin 2006; Scheffler 2006)? Which judgments need to be made regarding "new wars" (Münkler 2015) of our times including civil wars, wars among peoples and genocide?

This contribution takes place at the interface of both discussions. It recalls some insights of what is now called "orthodox" or "classic" just war theory as recently explained comprehensively in an introductory work by Helen Frowe (2011). In particular, it discusses some insights in "jus in bello," which is a part of the orthodox war theory, comprising a set of moral prescriptions when war has already started. Simultaneously, it tries to address a new area of concern in the ethics of war. This is the concern that just war theory has been all too quick in reasoning moral judgments about fatal actions as part of the soldiers' mission in war. As military personnel, soldiers are not only allowed to kill soldiers of the belligerent counter-party, they are even obliged to do so under circumstances that just war theory explains. Moral restrictions do apply to that scenario. But they are primarily restricted to principles of a "fair fight." The jus in bello is the theoretical approach that is dedicated to listing and explaining basic principles of restrictions in terms of a "fair fight." This includes the protection of civilians, obligations in treating prisoners of war, prohibitions of some types of weapons, and the important distinction between legitimate and illegitimate targets (Frowe 2011, 95117). Yet, in this moral framing, too, the obligations to fight in a fair way address primarily the commanders, not the single soldier.

The moral philosopher Jeff McMahan has recently initiated an important shift of attention and systematic change regarding the soldiers' moral obligations. He develops a theoretical approach to "killing in war" in the context of a broad ethical debate on "killing" (MacMahan 2003) and in the context of just war theory (McMahan 2011). This approach includes some challenges for traditional just war theory. In particular, McMahan introduces a criterion of "liability" that transforms the allowances of soldiers in war, even when fighting a just war (McMahan 2005). A sketch of this concept includes the following: presupposed, a soldier fights a war that needs to be classified as an "unjust war"; and presupposing that the soldier himself has contributed to severe war crimes. The soldier fighting the just cause nevertheless needs to apply a criterion of liability when intending to kill another soldier. He needs to assess if he is right to think that the enemy soldier has 
Angela Kallhoff

forfeited his right to life. He even must assess if the enemy is liable to be killed. This is, of course, a particularly challenging claim.

In this contribution, I wish to take up the issue of "justified killing in war" in the context of recent debates in the ethics of war. I shall start with a sketch of the concept of liability and develop the insights into a direction that McMahan does not focus on. I wish to argue that the issue of "moralities of warfare" does not only have to include a sophisticated approach to culpability and to the permissibility of killing in war. Moreover, to provide a fair assessment of the soldier's actions in war, I wish to present three aspects that contribute to a more thorough assessment of the soldiers' actions in war: I shall argue against a general moral exceptionalism regarding the "jus in bello." Instead of bracketing moral claims, basic moral insights need to be applied to the scenario of warfare without claiming a general exception. I shall then argue two consequences of this claim: a distinction of "just" and "unjust" warfare applying to soldiers and a more detailed assessment of moral guilt. ${ }^{1}$ This has important effects on the assessment of killing in war by soldiers. ${ }^{2}$

Yet, two reservations need to be made at the beginning. First, this discussion is restricted to the soldier as military personnel of a state army. For analytical clarity, it is necessary to start with this paradigm case of just war theory. I shall not debate other types of combatants, even though they certainly exist in each war. Second, I shall also interpret the military as part of a national defense institution. This is also far from regular. In my view, war ethics is well advised - at least so when opening new fields of concern - when not starting with the most complex scenarios that war always includes and presents. Instead, I start with what has been considered the "standard case," which is a violent inter-state conflict, fought by means of the military.

\section{The Framing: Classical Just War Theory}

Since ancient times, authors in political philosophy and in theology have debated the principles that distinguish a "just war" from other forms of warfare (Bellamy 2006, 15-114). It is also a particular trait of just war theory that has been fed by various sources. ${ }^{3}$ Until today, just war theory also spurs debates about the criteria

1 This claim is not new, but has been reasoned by moral philosophers who are committed to ethical cosmopolitanism. For a war ethics building on ethical cosmopolitanism, see Fabre 2012.

2 For our current project on the "moralities of warfare," including the perspectives of soldiers, see the following contributions (Kallhoff and Schulte-Umberg 2015 and Kallhoff and Schulte-Umberg 2017).

3 A very helpful illustration of the sources that have entered just war theory and that have shaped its current content is provided by Bellamy (Bellamy 2006, 8). This book also provides a particularly comprehensive exploration of the history of just war theory until 
that support the interpretation of a war as meeting the standards of moral allowances. A range of core principles have entered the Law of the Peoples and has, therefore, also received the status of official doctrines. The most well-known and possibly most important doctrine is that there is only one convincing just cause, which is national self-defense against a military attack that threatens a people both regarding its sovereignty and its territorial integrity (Walzer 2006, 58-63). The moral exemption of a general condemnation of war is the justified battle against an aggressor.

In discussing the classical frame of just war theory, it is also important to notice that various groups of moral principles need to be distinguished. First, principles always apply to a certain phase of war. The "jus ad bellum" discusses exceptional moral allowances and forbearances to go to war or to start a war. It discusses military aggression and its counterpart, military defense. The "jus in bello" instead explores principles once a war has started. It develops principles of fair fight, which have also entered international law. ${ }^{4}$ Recently, the debate on "jus post bellum" has also gained momentum, including an ethical debate on reasonable peace settlements after a war (Fabre 2016; Holmes 2016). On the one hand, principles are grouped according to the time-scale distinction "before war," "during war" and "after war." On the other hand, types of principles that also transcend this time-scale proposal have been reasoned. Broadly conceived, substantial, procedural, and pragmatic principles need to be distinguished.

The most important substantial criterion in jus ad bellum is the "just cause." If a nation plans to go to war, it needs to justify this endeavor in the international arena. Today, the only permissible just cause is national self-defense after a severely aggressive attack; yet in the tradition of just war theory, a range of causes has been accepted, including just punishment or the restoration of peace. As for procedural principles, it is, for example, important to announce the intention to go to war and to meet principles of proportionality. As for pragmatic principles, war needs to be a last resort, and there has to be a justified expectation of reasonable success. ${ }^{5}$ None of the criteria is uncontroversial. Yet, as a bedrock of war ethics they provide a theoretical frame for further discussion.

It is also important to notice that the field of war ethics is a much broader field than classical just war theory. War ethics does not only discuss criteria that allow

today. For an overview of religious theories of just war, see Reichberg, Syse \& Hartwell 2014.

4 See the Hague Convention (IV) Respecting the Laws and Customs of War on Land and its Annex: Regulations Concerning the Laws and Customs of War on Land (1907), https://ihl-databases.icrc.org/applic/ihl/ihl.nsf/INTRO/195?OpenDocument (accessed September 11, 2017) and the Geneva Conventions of 1949 and Additional Protocols, and their Commentaries https://ihl-databases.icrc.org/applic/ihl/ihl.nsf/vwTreaties1949.xsp (accessed September 11, 2017).

5 For a good explanation of each these criteria, see (Frowe 2011). 
Angela Kallhoff

for a military conflict and provide constraints to what is allowed and what is banned during a conflict. It also discusses civil wars, terrorist attacks, humanitarian intervention and all sorts of "new wars." In particular, going back to the underlying moral philosophy, the theoretical framing that has been proposed is multifaceted. It includes more or less classical strands of thought, including a discussion on the right of self-defense as exceptional moral allowance (Lazar 2009; McMahan 1994; McMahan 2014; Rodin 2002; Thomson 1991). It also includes "absolutist positions" that rely on the presumption that killing a person should never be allowed (Nagel 1972). Much of current war ethics is also presented as not relying on a single moral framework, but rather as combining various principles that need to be combined case-by-case and in discussing detailed thought experiments (Kamm 2007; 2011).

This contribution adds to the ongoing debates in war ethics at a particular point. In order to explain this systematic point of departure, I shall distinguish three important parameters in war ethics. The first parameter is related to the time-scale distinctions: my main concern in this contribution is the jus in bello, which is the theoretical aspect of just war theory that debates moral principles in conducting a war. I am concerned that these principles allow too much: even though McMahan and other philosophers have tried to place further restrictions on allowances to kill in war, the paradigm of justified self-defense still overshadows the debate. The second parameter is the focus on the actions of soldiers that, in war, have fatal effects on soldiers of the counter-party. Soldiers kill in war. And even though the act of killing has never been accepted as right, soldiers are, for good reasons, exempt from moral condemnation when killing the enemy. But do the current presumptions regarding reasonable exemptions suffice? The third parameter is an interpretation of "morality" and the goals of a moral investigation in this context. Yet, soldiers also fight a war for their own reasons, and some of those function as "moral reasons." Taking the "moralities of warfare" seriously also includes an investigation of that perspective.

\section{Against Moral Exceptionalism of the Jus in Bello}

Just war theory has been interpreted as distinguished by criteria that set one phase of war apart from another phase. The jus ad bellum focuses on the pre-war phase. It argues that a range of criteria needs to be met to regard a war as in accordance both with moral rules and with the Law of the Peoples. Yet this empirical distinction is correlated with normative distinctions, including just causes, procedural and pragmatic criteria. As already noted, different principles apply to each phase of war.

6 For an overview over recent issues in just war theory, see (Bellamy 2006, 115-228). 
Justifiable Killing in War?

As for jus ad bellum and jus in bello a consensus has evolved since the early twentieth century that takes jus ad bellum and jus in bello as strictly separated. Walzer restates this insight when claiming that war is always judged twice: "[j]us ad bellum requires us to make judgments about aggression and self-defense; jus in bello about the observance or violation of the customary and positive rules of engagement. The two sorts of judgment are logically independent." (Walzer 2006, 21) According to this approach, which I shall call the "thesis of separation," there is no debate about whether or not a war has a just cause in jus in bello. Instead, the criteria in jus ad bellum and jus in bello are so different that even the following scenario can happen: "[t]hus, a justifiable war might be waged unjustly; an unjust war may be waged justly.” (Bellamy 2006, 128)

One of the most intriguing debates of current just war theory focuses on this distinction between jus ad bellum and jus in bello as also including a systematic switch. The separation of both has a pragmatic reason; it serves the goal not to overload an ongoing war with a moral reasoning that also includes the condemnation of one of the fighting parties. It might even be said that the rationale of the jus in bello rests to some degree on consequentialist, even pragmatic reasoning: in a war scenario everything that counts is the prevention of a worst case scenario. Therefore, normative rules need to be established that prevent the biggest evils - possibly agreed upon by both sides. Civilians need to be protected from severe harm, particularly harmful weapons causing widespread devastation need to be banned, including chemical weapons, and the use of the military needs to be justified as related to military targets. Agreement among fighting parties can possibly be expected when the reduction of severe harm on both sides is at stake.

A second argument is consequentialist: if the jus in bello included a discussion on "just" vs. "unjust cause," the party on the unjust side would have nothing to lose. And in a war scenario this is one of the biggest evils that could happen: persons and parties who are under enormous pressure and in life-threatening scenarios and who have nothing to lose are assumed to act particularly violent. This minimizes the chances of reaching any peace-settlement in a post-war scenario. ${ }^{7}$ It should also be noted that an important cause of continued warfare is the fact that each party thinks that they are fighting for a just cause. This means that really settling the issue as to whether or not war is a "just war" in accordance with the just-war paradigm is unlikely to happen during war itself. Consequently, the jus in bello has been separated from issues of "just cause." Instead, it focuses on principles of fairness in fighting, which is the only chance to curtail warfare and to bring war to an end.

Yet, recently, authors in moral philosophy have questioned this reasoning with regard to its normative implications. They say that the exemption of the jus in bello from justificatory moral arguments is not only wrong for theoretical reasons,

7 For more detailed arguments about the necessary limitations of moral argument in jus in bello, see the contributions in (Rodin and Shue 2008). 
Angela Kallhoff

but that it also has another severe effect, which cannot be overlooked any more. It leads to an assessment of killing in war that is flawed. There are of course reasons why killing in war is not judged on a par with murder. Yet, the strict separation between jus ad bellum and jus in bello has morally questionable implications: whereas it might be right to grant soldiers who fight a just war a general exemption from being accused of murdering enemy soldiers - note that this does not include war crimes and crimes against civilians! - this same reservation does not necessarily apply to soldiers fighting in an unjust war. ${ }^{8}$

I shall not discuss the complex issue of whether or not moral allowances can ever be reasoned regarding murder here. Instead, I shall focus on the more general claim that the jus in bello needs to be assessed by means of highly exceptional moral claims. As a first step, it is helpful to reject a radical form of exceptionalism, which is "realism." Realism claims that war is just another way of doing politics. In a realist paradigm, war is a realm of "necessity and duress" (Walzer 2006, 4-13). This allows for a general exemption of moral standards. Yet, most of what has been written in just war theory in the last decades aims at rejecting this general exceptionalism. In some important respects, war also needs to be judged against the background of moral principles.

As a second step, it is necessary to discuss an implication of exceptionalism. This is encapsulated in the doctrine of the "moral equality of combatants." This doctrine states that the thesis of separation has an important implication for the jus in bello. When the overall question as to whether or not this war is right is spared from consideration, jus in bello lacks an important ingredient. There is no division between a party fighting a just war and soldiers who possibly fight an unjust war. The orthodox jus in bello states precisely this; it is distinct from jus ad bellum in that it does not include judgments over moral rightness of either the aggressor or those defending themselves against aggression; both need to be considered in light of a jus in bello that claims fair rules of fighting.

This claim of equality has been explained as the argument of the doctrine of the "moral equality of combatants." However, this doctrine does not only say that all combatants have an equal set of rights, but it also includes, according to some philosophers, an equal right to kill (McMahan 2011, 4). Actually, Walzer thinks that soldiers should never be blamed for what they do when participating in a war because they endure hell. They have to follow orders. Moreover, he states: " $[\mathrm{t}]$ hough there is no license for war-makers, there is license for soldiers, and they hold it without regard to which side they are on; it is the first and most important of their war rights." (Walzer 2006, 36) This is yet another type of moral exceptionalism included in the orthodox jus in bello.

Even though it is granted that the soldiers' acts of killing in war need to be assessed in a more complex framework than just identifying it with an act of murderer, moral philosophers claim that a more thorough moral assessment than

8 For similar arguments, see (Bellamy 2006, 128-130). 
offered by the classical jus in bello is needed. This also includes a new debate questioning whether the distinction between jus ad bellum and jus in bello signals a normatively radical difference. Imagine a situation in which a war has been assessed as a perfectly "just war" in that all criteria were met - most importantly, the just cause of self-defense after severe aggression; and simultaneously, this war is extraordinarily brutal and condemnable, even considering that no rules were broken, such as the use of illegal weapons and attacks committed against civilians. Is it still right to separate the jus-in-bello assessment from declaring this war as "unjust"??

As a consequence of the arguments, the field is now open to a debate in war ethics that is particularly complex. Instead of granting the jus in bello moral exceptionalism, moral philosophers have developed criteria for distinguishing between "justified soldiers" and "unjustified soldiers" - broadly conceived. ${ }^{10}$ It is not the space here to portray this debate. I have the more modest goal of presenting two ways to fill this space in the next section. I shall discuss the distinction between "justified soldiers" and "unjustified soldiers" in war ethics; and I shall explain why the soldier's own view also needs to be taken into account. Before, the most important insights shall be summarized.

So far, I have defended an approach to jus in bello that breaks with a key reservation of orthodox just war theory. According the orthodox view, the moral debate regarding war has two different functions to fulfill. The jus ad bellum needs to develop criteria for judging if military aggression or a military defense is right. Even though war is a crime, exemptions from a general moral forbearance of waging war have been argued. The jus in bello, instead, develops criteria for fighting war by fair means. It argues that moral constraints need to be restricted to rules of fairness, including, among others, the rules of proportionality and likely success, the protection of civilians, the strict forbearance of particularly harmful weaponry, and the care for prisoners of war (Frowe 2011, 95-117). I have also argued that the thesis of separation that lurks in the background is flawed. Even though the concerns of fairness in war are still of utmost importance, they do not cover the whole set of moral concerns regarding warfare. At a minimum, the allowance to kill the enemy needs to be reassessed again and again, and in particular, against the backdrop of different types of warfare and of new technologies as well.

9 For a discussion of this case which also coheres with opinions in the tradition of just war theory, see (Bellamy 2006, 128-130).

10 An overview about most important contributions to this debate is presented in (Rodin and Shue 2008). 
Angela Kallhoff

\section{The Debate on Justified and Unjustified Soldiers}

When fighting a war, soldiers are placed in a situation of exceptional circumstances. The sentence that, in this context, usually makes sense is the following: "War is hell." Whereas the orthodox just war theory offered a simple formula for exculpating soldiers by granting an equal right to kill the enemy, recent war ethics denies this right. This does not say that killing in war is judged on the same grounds as killing during peace. This would be highly unfair. Instead, war ethics has tried to establish criteria not only for weighing the moral fault of soldiers when killing soldiers of the hostile military, but also criteria for reassessing the right to kill itself.

Starting with the latter, the leading paradigm in judging killing in war used to be "self-defense." Let us assume that a war is clearly an unjust war. It is military aggression that lacks a just cause and in addition it might lack further qualifying criteria, such as proportionality or last resort. One might argue that soldiers who fight this war cannot be judged as doing the right thing when killing in war. Even worse, they cannot be excused from killing in war. This seems rather harsh and needs to be qualified. Philosophers have tried to add some qualifications.

The most important one is related to the category of "liability." McMahan explains that it is wrong to conceive of killing in war, even when done by soldiers, as permissible by the "right to kill." Instead, he explains that a moral exploration needs to focus on the person who will be killed. The basic question is not whether or not it is allowed to take the life of this person, but whether or not she is either a legitimate target or an "innocent" victim (McMahan 2011,8). As for soldiers, they have, in a way, lost their status of innocence, in particular when fighting an unjust war. Yet, the first philosophical point is: "[t]o attack someone who is liable to be attacked is neither to violate nor to infringe that person's right, for the person's being liable to attack just is his having forfeited his right not to be attacked, in the circumstances." (McMahan 2011, 10) This qualification is controversial. Yet, regarding a moral assessment of killing in war, it is particularly helpful: in a normative perspective it divides the acts of killing not only into acts that are allowed vs. acts that are never allowed, but it also helps to assess the special situation on the battlefield. It helps to distinguish between necessary and unjust threats in war. In McMahan's words: "I have suggested that the criterion of liability to attack in war is moral responsibility for an objectively unjustified or wrongful threat. The notion of a wrongful threat is, however, ambiguous. In its primary sense, a wrongful threat is a threat of wrongful harm - that is, harm to which the victim is not liable posed by action that is objectively wrong. In most instances in which unjust combatants attack just combatants they pose a wrongful threat in this sense. Yet when just combatants attack unjust combatants within the limits of proportionality, they neither act wrongly nor wrong their victims." (McMahan 2011, 38)

This proposal is highly controversial. But in one respect, it is in line with recent debate on killing either in self-defense or as part of a collective endeavor of a just 
war. The normative implication of killing on the battlefield is an offense against the right of the enemy soldier - he also has a right to live. But no-one can really take away a right to live. Instead, what matters on moral grounds is whether or not it is ever allowed to kill, even when the judgment is right that by providing herself a lethal threat to another person, she has forfeited her right to integrity of life and body (Rodin 2002). Whereas some justify this with reference to a "higher goal," the proposal of McMahan and others points in another direction. It speaks about the willful forfeiture of a right to live by joining a military that fights an unjust war and by committing crimes in war. ${ }^{11}$

The debate on justifiable killing in war does not end here; actually it starts precisely at this point. In particular, it is not comprehensively attached to the distinction of soldiers fighting a war that qualifies as "just war" according to the principles of just war theory or fighting an unjust war respectively. A real matter of concern is also the distinction between exceptional moral permissibility and justified excuses (McMahan 2011, 110-115). It is possible to judge an act as morally wrong, yet nevertheless under specified circumstances as morally permissible. It is also possible to judge an act as morally flawed, yet excusable. Whereas the former makes it difficult to argue justifiable acts of killing, ${ }^{12}$ the latter poses no particular difficulties when arguing for soldiers who fulfill their duty on the battlefield. Excuses include the duress that soldiers suffer on the battlefield and epistemic limitations in assessing the situation on the battlefield (Shue 2008, 99). Yet, they do not contribute to changing the deontic parameters that apply to an act: killing is still wrong. An additional criterion for excuses - even though applied to morally wrong acts - is lack-of-control conditions. Soldiers do not only encounter difficulties trying to understand what is going on in their surroundings, they also have no influence on the overall cause of events, which is decided by the army or the regime, but not by themselves (Fabre 2012, 75-78).

In addition to these proposals for a more detailed assessment of killing in war, Kutz (2005) argues that, even after decades of debate on liability and its consequences, a somehow basic version of the "equality of combatants" thesis is still in place. Under so-called "collectivist approaches to war," a main concern is that it is not appropriate to distinguish sharply between the acts of soldiers, on the one side, and war as a collectivist enterprise undertaken by states and commanded by military leaders on the other. Kutz notes that "the fact that my nation is at war, not me, does not absolve me of responsibility towards my enemy, but it does create a normatively distinct relation between us, one structured through a set of rules specific to our interrelationship as individual members of warring nations." (Kutz $2005,173)$ The encounters between soldiers are also shaped by rules of a politically collective event. Nevertheless, does the distinction between individual moral

11 For the controversial debate on "liability" in war ethics, see also Bazargan 2013; Fabre 2009; Hurka 2007; McMahan 2005.

12 For a discussion of possible cases, see Kamm 2011, 119-168. 
permissions and collective moral permissions apply? In particular: "[t]he privilege to kill as part of a collective is not a moral permission attaching to the individual soldier." (Ibid.) Yet, the difference between these types of permissions is not a moral one; instead, it is explained with reference to the collective of which the soldiers are a part. In a collective that follows rules of authorization and obedience, members of that collective are supposed to authorize each other to use violence for political means. ${ }^{13}$

To sum up this section, it is important to discuss the moral status of soldiers anew. Yet, a broadly conceived distinction between "just soldiers" fighting a just war and "unjust soldiers" being involved in an unjust war is not convincing. Even though it is right to reintroduce the criteria of "just and unjust war" into the jus in bello, the soldier's stance does not comprehensively depend on this distinction. Some proposals to fulfill the aim of a more detailed approach to killing in war have been presented. They include a reassessment of a presumptively general "right to kill," the debate surrounding the category of "liability" in terms of the risk of being killed on the battlefield due to a significant moral fault, and a rejection of the full burdens of responsibility because of fair excuses. At least when fighting a just war, soldiers also perform an honorable duty. And even in unjust wars, soldiers are not free to judge and to act, but act under duress, under severe epistemic limitations and without full control of their actions. They are part of a collective that follows rules, in particular, the rule of obedience.

\section{And the Soldiers' Own Viewpoint?}

Even though this contribution already covers a range of issues of the moral concerns regarding the soldier's stance in war, there is still another severe limitation of orthodox just war theory that needs to be addressed. Soldiers are actors who are obliged to follow the commands in the military. Yet, their viewpoints do not count. Soldiers are regarded as military personnel; they have the duty to obey the commands of military leaders. In a war of self-defense of a nation they are also agents who dedicate more than their work power to the honorable cause of defending the nation. This includes fatal action and the use of lethal weaponry. Depending on his education as a soldier, she is in some armies taught to reject orders that do not cohere with moral principles in fundamental ways. But the motives that count for her are neither a matter of decision, nor does he choose a personal approach to the justice of the goal that he fights to accomplish together with his comrades. Overall, soldiers live in a different world than the civil everyday world. And they have made promises that they need to live up to. In sum, soldiers are in an exceptional situation. But orthodox just war theory has not given attention to this exceptionalism, either.

13 For arguments against this proposal, see McMahan 2011, 82-84. 
Justifiable Killing in War?

Recently, this blind spot of orthodox war ethics has been criticized. How could the justice of warfare ever be assessed in a fair manner, without also drawing attention to the commitment of single soldiers in fighting a war? To initiate this discussion I wish to refer to observations that have been reported by Nancy Sherman (Sherman 2010). Sherman explores personal assessments of former soldiers in the United States, especially the views of veterans. This includes reports of her father, who, at the time of her study, was a veteran of WWII. Overall, she claims that to overcome war trauma it is particularly important for veterans to regard their own fight as part of an endeavor that was a "just war" or at least a particularly worthwhile enterprise at that time. In this light, Sherman comments on the reports of her father, a commander during WWII: "[i]n his case, he does have time to reflect, and wonders if the fight is worth the horrific ruin and devastation he anticipates and then sees up close in dying men and mutilated bodies. That sense of his own responsibility for the specific war he fights is there, whether he talks about it openly or not. The worry is about proportionality, the ratio of the good anticipated to all the carnage. Is it worth it? In the war he fought, he believes it was, then and now, as most do. But the point I am making is that the moral oversight is internal. Yes, it is not just about what he did as an individual soldier, in his case, administering inoculations and relief to the war-torn and maimed. It is also about the war he was in. That frames his perspective and his responsibility." (Ibid., 46)

The report of Sherman and her interviews with war veterans open a new range of difficult issues. The question of whether or not the war was worth the soldier's commitment and whether or not it was a "just war" appears to matter to the soldier himself. Sherman discusses the situation of veterans. They are in the comfortable and simultaneously difficult situation to draw conclusions about wars that are at least for themselves over. Yet, some more general preliminary conclusions can be presented. First, the discussion of the soldiers' own interpretations and views of warfare contributes to the proposal of Kutz (Kutz 2005). Soldiers interpret their acts in the context of commitments not only to the military, but also to the joint commitment of comrades fighting together (Kallhoff and SchulteUmberg 2015, 447). One cornerstone for understanding this complex relationship is an interpretation and exploration of what we call the "morality of warfare." Soldiers neither reason about the moral principles that guide their actions, nor do they simply share worldviews and insights that they have learned and acquired in various social surroundings. Instead, they share norms of a collective that works with a complex pattern of moral norms, including also the norms of religious worldviews. ${ }^{14}$ In particular, soldiers try to frame their actions in ways that represent reasonable goals and core commitments according to their moral worldviews. Even though these facts do not account for exculpation, they are important

14 For an exploration of the religious aspects of war morale in WWI, see the contribution of T. Schulte-Umberg in this volume. 
Angela Kallhoff

in addressing the exceptionalism of orthodox just war theory from a different angle. Soldiers need to be taken seriously in their worldviews, too.

\section{Conclusion}

Overall, the "morality" that has been explored in the context of orthodox just war theory is far too restricted. It has many blind spots, including the ones enumerated in this contribution. It falls short of addressing "killing in war" in an adequate framework. Moreover, the assessment of killing in war is often too one-sided. It offers little help in discussing the distinctions between killing in just and unjust wars likewise. In this contribution, I have tried to remedy this problem by arguing that the moral exceptionalism of jus in bello should be rejected.

The steps that have been argued cohere with recent debates in the domain of moral philosophy. Authors generally begin by rejecting the doctrine of the "moral equality of combatants" and its background-assumption. In orthodox just war theory, the theory that debates whether or not the beginning of war is right - the jus ad bellum - has been logically separated from jus in bello. In addition, jus in bello has been restricted to principles of a fair fight. One of the major mishaps in that theory is that it appears to propose either a general allowance of soldiers to kill other soldiers or a moral assessment that does not draw on detailed moral distinctions.

A first proposal to heal this deficit is the rejection of the moral-equality thesis. Moral philosophers argue that the difference between a just and an unjust war also needs to bear somehow on the moral status of soldiers. In section two, I have also questioned an all too broad distinction along these lines. Arguments that support this view highlight duress, epistemic limitations and lack of control. In addition, the case needs to be made for war as a collective enterprise. Even though collectivity is not the backdrop for a general exculpation, the duties of soldiers in war and their commitment to fulfilling military goals need to be taken seriously. In the last section, I have argued that this insight also leads into another direction: soldiers are not only committed to fulfilling their duty, but they also participate in and shape a collective approach to a "morality of warfare" of their own. Even though this does not necessarily bear on moral allowances or forbearances, an exploration of this type of morality of warfare is obligatory to do justice to the soldier's stance.

\section{References}

Bazargan, S. (2013). Complicitous Liability in War. Philosophical Studies, 165, 177-195. Bellamy, A. J. (2006). Just Wars: From Cicero to Iraq. Cambridge, UK; Malden, MA: Polity Press. 
Coady, C. A. J. (2004). Terrorism, Morality, and Supreme Emergency. Ethics, 114(4), 772789.

Fabre, C. (2009). Guns, Food, and Liability to Attack in War. Ethics, 120(1), 36-63.

Fabre, C. (2012). Cosmopolitan War. Oxford: Oxford University Press.

Fabre, C. (2016). Cosmopolitan Peace. New York, NY: Oxford University Press.

Frowe, H. (2011). The Ethics of War and Peace: An Introduction. London and New York: Routledge.

Goodin, R. E. (2006). What's Wrong with Terrorism? Cambridge, UK; Malden, MA: Polity Press.

Holmes, R. L. (2016). Pacifism: A Philosophy of Nonviolence. New York: Bloomsbury. Hurka, T. (2007). Liability and Just Cause. Ethics \& International Affairs, 21(2), 199-218.

Kallhoff, A. / Schulte-Umberg, T. The Committed Soldier: Religion as a Necessary Supplement to a Moral Theory of Warfare. Politics, Religion \& Ideology, 16(4), 434448.

Kallhoff, A. / Schulte-Umberg, T. New Views on the Theory of The Just War: The Turning to the Soldier and Questions of War Morality. German Journals of Philosophy, 652017 (4), 762-780.

Kamm, F. M. (2007). Intricate Ethics: Rights, Responsibilities, and Permissible Harm. Oxford; New York: Oxford University Press.

Kamm, F. M. (2011). Ethics for Enemies: Terror, Torture, and War. Oxford; New York: Oxford University Press.

Kutz, C. (2005). The Difference Uniforms Make: Collective Violence in Criminal Law and War. Philosophy \& Public Affairs, 33(2), 148-180.

Lazar, S. (2009). Risk, and Killing in Self-Defense. Ethics, 119(4), 699-728.

McMahan, J. (1994). Self-Defense and the Problem of the Innocent Attacker. Ethics, 104(2), 252-290.

MacMahan, J. (2003). The Ethics of Killing: Problems at the Margins of Life. New York: Oxford University Press.

McMahan, J. (2005). The Basis of Moral Liability to Defensive Killing. Philosophical Issues, 15, 386-405.

McMahan, J. (2011). Killing in War. Oxford: Oxford University Press.

McMahan, J. (2014). Self-Defense Against Justified Threateners. In Frowe, H. \& Lang, G. (eds.), How We Fight. Ethics in War. Oxford: Oxford University Press, 104-137.

Münkler, H. (2015). New Wars. Reinbek bei Hamburg: Rowohlt Paperback Publishing Company.

Nagel, T. (1972). War and Massacre. Philosophy \& Public Affairs, 1(2), 123-144.

Reichberg, G., Syse, H. \& Hartwell, N. (2014). Religion, War, and Ethics: A Sourcebook of Textual Traditions. New York: Cambridge University Press.

Rodin, D. (2002). War and Self-defense. Oxford and New York: Clarendon Press; Oxford University Press.

Rodin, D. \& Shue, H. (eds.). (2008). Just and Unjust Warriors: The Moral and Legal Status of Soldiers. Oxford and New York: Oxford University Press.

Scheffler, S. (2006). Is Terrorism Morally Distinctive? Journal of Political Philosophy, 14(1), 1-17.

Sherman, N. (2010). The Untold War. Inside the Hearts, Minds, and Souls of Our Soldiers. New York and London: W. W. Norton \& Company. 
Shue, H. (2008). Do We Need a "Morality of War"? In Rodin, D. \& Shue, H. (eds.), Just and Unjust Warriors. The Moral and Legal Status of Soldiers. Oxford and New York: Oxford University Press, 87-111.

Thomson, J. J. (1991). Self-Defense. Philosophy \& Public Affairs, 20(4), 283-310.

Walzer, M. (2006). Just and Unjust Wars: A Moral Argument with Historical Illustrations. New York: Basic Books.

Angela Kallhoff, Department of Philosophy, University of Vienna, Universitätsstr. 7, 1010 Vienna, Austria, e-mail: angela.kallhoff@univie.ac.at

Citation: Kallhoff, Angela: "Justifiable Killing in War? For Taking the Soldier's Stance Seriously in War Ethics”, in: Kallhoff, Angela / Schulte-Umberg, Thomas (eds.): Moralities of Warfare and Religion (J-RaT 2018 / 1) pp. 6-20.

Datum der Publikation: 16.07.2018 